\title{
Pollen analysis of honeybee rectum as a method to record the bee pollen flora of an area*
}

\author{
Maria Dimou, Andreas Thrasyvoulou \\ Laboratory of Apiculture \& Sericulture, Faculty of Agriculture, Aristotle University of Thessaloniki, Agroktima \\ Panepistimiou, 57001, Thermi Thessaloniki, Greece
}

Received 25 June 2008 - Revised 16 October 2008 - Accepted 22 October 2008

\begin{abstract}
Pollen is very important for the bees' nutrition and it is necessary for their survival and reproduction. In this work we studied the possibility of recording the pollen flora of an area by examining the pollen content of the rectum of honeybees (Apis mellifera L.) and comparing the results to these coming from pollen traps. We concluded that the pollen analysis of the rectum of honeybees could be used as a fast screening method of the bee flora of an area. However, for quantitative results, additional methods such as pollen pellet analysis should be applied.
\end{abstract}

Apis mellifera / nurse bees / pollen consumption / melissopalynology

\section{INTRODUCTION}

Pollen is very important for the bees' diet and it is necessary for their survival and reproduction (Dietz, 1978). Pollen consumption is significantly correlated to the age and the activities of the honeybee (Dietz, 1978; Eischen et al., 1984; Crailsheim et al., 1992; Hrassnigg and Crailsheim, 1998; Naiem et al., 1999; Loidl and Crailsheim, 2001). Worker bees start to consume pollen just a few hours after emerging and this amount reaches a maximum when the bees are four to nine days old (Zherebkin, 1965; Hagedorn and Moeller, 1967; Haydak, 1970; Crailsheim et al., 1992). Pollen consumption varies with different worker-larvae ratios. More pollen is consumed when more brood is present (Al-Tikrity et al., 1972; Pearson and Braiden, 1990; Camazine, 1993; Hrassnigg and Crailsheim, 1998; Pankiw et al., 1998; Dreller et al., 1999; Dreller and Tappy, 2000). Generally, nurse bees consume high quantities of pollen compared to foragers or drones (Crailsheim et al.,

Corresponding author: M. Dimou, mdimou@agro.auth.gr

* Manuscript editor: Jacqueline Pierre
1992; Szolderits and Crailsheim, 1993; Naiem et al., 1999).

Considering that pollen is required for growth of honey bee colonies, the knowledge of bee flora in an area constitutes a basic tool for the development of apiculture. Pollen traps have been used widely as a method to record the pollen flora of an area (Severson and Parry, 1981; Biesmeijer et al., 1992; Telleria, 1993; Pearson and Braiden, 1990; Coffey and Breen, 1997; Andrada and Telleria, 2005; Dimou and Thrasyvoulou, 2007). However, the use of pollen traps is not always feasible for some bee species nor desirable, since it may influence the nectar foraging behaviour of the colony in a negative way (McLellan, 1974; Webster et al., 1985; Duff and Furgala, 1986; Fewell and Winston, 1992; Dreller et al., 1999).

Pollen is transported to the honey stomach and then removed into the midgut where digestion and absorption occur. Posterior to this is the rectum where water and feces are stored until the bee exits the hive and defecates (Seeley, 1995). Thus, pollen analysis of the rectum of the bees could be used as an alternative method to record the bee flora of an area. However, the use of this method 
is limited (Ramírez-Arriaga and MartínezHernández, 1998; Oliveira et al., 2002) and no data about its validation exists.

In this research, we examined the possibility to study the bee pollen flora of an area by analysis of the pollen content from the rectum of honeybees. To validate this method, we compared the pollen data collected from the bee rectum to that coming from the pollen trap analysis and we investigated the sampling procedure considering the amount of pollen consumed by the honeybees.

\section{MATERIALS AND METHODS}

The experiments took place at an apiary located on the farm of the Aristotle University of Thessaloniki (Greece). We fitted two pollen traps (A and $\mathrm{B}$ ) in the entrance of two respective hives of Apis mellifera L., during spring. After a few days, we marked several newly emerged bees from each colony. The same procedure was repeated two days later. We collected 40 marked nurse bees from each colony when they were seven-days-old and examined their rectum content for pollen. We removed and weighed the rectum and we mixed it by vortex with $1 \mathrm{~mL}$ distilled water in a test tube. We then spread $50 \mu \mathrm{L}$ of the solution onto a $22 \times 22 \mathrm{~mm}$ area on a slide. Ten fields of view distributed uniformly over the area were analysed at a magnification of 400X using light microscopy, counting on average $753 \pm 342$ (mean \pm sd) pollen grains per slide.

To minimize and simplify the sampling procedure, we also randomly collected twenty honeybees of no particular age from one hive. The pollen content of the rectum of these honeybees was compared to the pollen content of the rectum of a respective number of seven-days-old nurse bees from the same hive to investigate whether the higher pollen consumption of nurse bees could affect the results of the study. We removed and weighed the rectum of the bees, we mixed it with $1 \mathrm{~mL}$ distilled water and examined $50 \mu \mathrm{L}$ of the solution as mentioned above under a microscope, counting on average $688 \pm 379$ (mean $\pm \mathrm{sd}$ ) pollen grains per slide.

In spring, when the brood area expands, the amount of pollen collected increases as does pollen consumption. On the contrary, in autumn the bees consume much less pollen. Thus, to ensure that the amount of pollen consumed by the honeybees did not affect the results of the study, the same experiments were repeated during autumn.
Finally, during the experiments, we collected daily the trapped pollen from the two hives. We thoroughly mixed $10 \%$ of the pollen loads of the initial trapped amount and then diluted it in distilled water (1:10) (Dimou et al., 2006). The pollen grains of $50 \mu \mathrm{L}$ of the solution were analysed as mentioned above, counting on average $645 \pm 228$ (mean $\pm \mathrm{sd}$ ) pollen grains per slide.

The identification of the pollen types was carried out using the reference slide collection of the studied area from the Laboratory of Apiculture and Sericulture of Aristotle University (Dimou and Trasyvoulou, 2007).

The experiments were restricted to a short time period to avoid major changes in the pollen flow that could have an effect on the differences between the pollen pellets and the bee rectum analysis. Indeed, the daily pollen abundance collected from the colonies did not show statistically significant differences (minimum observed value $P=0.105$ ).

The nonparametric Mann-Whitney test was used to compare the results between the colonies, between the pollen trap and the bee rectum analysis, and between the group of the nurse bees and the group of the various-age bees. The non-parametric test was preferred since the normality and homogeneity of variance assumptions did not hold in all cases. The normality assumption was tested using the Kolmogorov-Smirnov test and the homogeneity of variance was tested using Levene's test. The observed significance level ( $P$-value) of the nonparametric tests was estimated by Monte-Carlo simulations (Mehta and Patel, 1996). The analyses were carried out using SPSS V.12 enhanced with the module Exact Tests. The significance level of all the statistical tests was set at $\alpha=0.05$.

\section{RESULTS}

The weight of the rectum of the nurse honeybees during spring $(26.9 \pm 13.3 \mathrm{mg})$ was not statistically significantly different from the weight in autumn $(28.0 \pm 12.3 \mathrm{mg}) P=$ $0.727)$. However, we found statistically significant differences in the rectum weight between the sample of nurse bees and the sample of various-age honeybees $(P<0.001)$. The mean weight and standard deviation of the rectum at the last group was $8.9 \pm 3.1 \mathrm{mg}$ in spring and $9.5 \pm 2.8 \mathrm{mg}$ in autumn.

During spring we recorded 18 pollen types in the rectum of the nurse bees and 17 pollen 
Table I. Frequency of pollen types in pollen traps and nurse bee rectums during spring.

\begin{tabular}{|c|c|c|}
\hline \multirow[b]{2}{*}{ Pollen type } & \multicolumn{2}{|c|}{ Percentage (\%) of pollen grains in } \\
\hline & $\begin{array}{l}\text { Pollen trap } \\
(\text { mean } \pm \text { sd })\end{array}$ & $\begin{array}{c}\text { Rectum } \\
(\text { mean } \pm \mathrm{sd})\end{array}$ \\
\hline Adonis Type & $11.92 \pm 4.66$ & $14.89 \pm 8.32$ \\
\hline Campsis radicans (Bignoniaceae) & $1.07 \pm 1.44$ & $2.24 \pm 4.22$ \\
\hline Carduus Type & $0.02 \pm 0.03$ & $0.12 \pm 0.37$ \\
\hline Chenopodiaceae & $2.04 \pm 4.16$ & $1.10 \pm 2.34$ \\
\hline Cistus sp. (Cistaceae) & $1.56 \pm 2.59$ & 0 \\
\hline Convolvulus arvensis (Convolvulaceae) & $2.28 \pm 0.97$ & $1.94 \pm 2.51$ \\
\hline Daucus carota (Apiaceae) & $4.10 \pm 4.30$ & $3.92 \pm 5.63$ \\
\hline Elaeagnus angustifolia (Elaeagnaceae) & $0.52 \pm 0.38$ & $0.91 \pm 1.78$ \\
\hline Ligustrum japonicum* (Oleaceae) & $3.04 \pm 2.27$ & $6.80 \pm 7.92$ \\
\hline Olea europea $*($ Oleaceae $)$ & $0.84 \pm 0.94$ & $16.63 \pm 14.81$ \\
\hline Parthenocissus inserta* (Vitaceae) & $17.53 \pm 9.15$ & $1.04 \pm 1.52$ \\
\hline Pastinaca sativa* (Apiaceae) & $9.00 \pm 7.95$ & $0.65 \pm 1.15$ \\
\hline Pinus sp. (Pinaceae) & 0 & $0.73 \pm 3.02$ \\
\hline Sisymbrium irio (Brassicaceae) & $10.71 \pm 3.59$ & $11.18 \pm 8.08$ \\
\hline Taraxacum officinale* (Asteraceae) & $2.38 \pm 1.25$ & $0.29 \pm 0.44$ \\
\hline Thymus Type & 0 & $0.04 \pm 0.17$ \\
\hline Tilia intermedia (Tiliaceae) & $3.41 \pm 1.69$ & $3.43 \pm 2.02$ \\
\hline Tribulus terrestris (Zygophyllaceae) & $0.30 \pm 0.32$ & $0.15 \pm 0.41$ \\
\hline Trifolium sp.* (Fabaceae) & $29.30 \pm 4.83$ & $1.22 \pm 1.26$ \\
\hline Unidentified & 0 & $32.71 \pm 10.52$ \\
\hline
\end{tabular}

* Statistically significantly different according to Mann-Whitney test $(\alpha=0.05)$.

types in the trap. Most important with regards to their percentage frequency in the traps and/or the rectum were: Adonis Type, Ligustrum japonicum, Olea europea, Parthenocissus inserta, Sisymbrium irio and Trifolium sp. (Tab. I, Fig. 1). All these pollen types were found both in bee rectum and pollen trap analysis. Cistus sp. was located only in the pollen trap; and Thymus Type and Pinus sp. were recorded only in the rectum analysis (Tab. I). Statistical analysis showed significant differences with respect to the percentage frequency of the pollen types between honeybee rectum and pollen trap analysis in several cases: Olea europea, Ligustrum japonicum, Parthenocissus inserta, Pastinaca sativa, Taraxacum officinale and Trifolium sp. (Tab. I).

During autumn we recorded 16 pollen types in the rectum of the nurse bees and 18 pollen types in the trap. Most important with regards to their percentage frequency in the traps and/or the rectum were: Erica manipuliflora, Hedera helix, Phoenix Type, Polygonum aviculare and Sisymbrium irio (Tab. II, Fig. 1). All these pollen types were found both in bee rectum and pollen trap analysis. The two pollen types (Citrus Type and Lagerstroemia indica) found only in the trap were present in very small concentrations $(<1 \%)$ (Tab. II). Statistical analysis showed significant differences with respect to the percentage frequency of pollen types between honeybee rectum and pollen trap analysis in six cases (Tab. II).

The pollen preferences of honey bees can be genetically influenced and thus vary among the colonies of an apiary (Page et al., 1995; Pankiw et al., 2002). In this study, both colonies collected the same pollen spectra except one taxon with minor abundance (Citrus Type) which was collected only from one hive. Statistical analysis between the colonies relative to the percentage frequency of each pollen type showed no significant differences in spring (minimum observed $P=0.095$ ); while there were three cases (Rubus ulmifolius, Scholmus hispanicus and Sonchus Type) involving minor pollen sources during autumn (Fig. 2). 


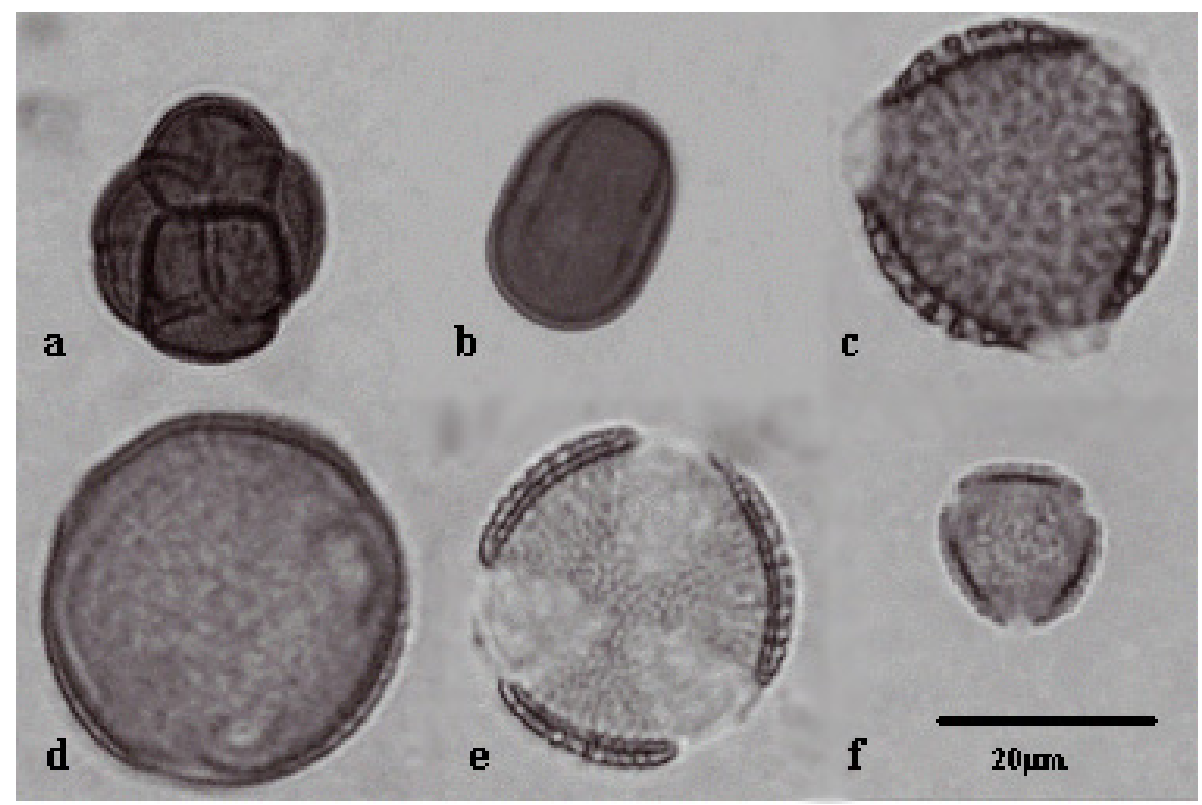

Figure 1. Main pollen taxa found in pollen loads and bee rectum: (a) Erica manipuliflora, (b) Polygonum aviculare, (c) Ligustrum japonicum, (d) Parthenocissus inserta, (e) Sisymbrium irio, (f) Olea europea. All the plates are in the same scale.

Table II. Frequency of pollen types in pollen traps and nurse bee rectums in autumn.

\begin{tabular}{lcc}
\hline \multirow{2}{*}{ Pollen type } & \multicolumn{2}{c}{ Percentage $(\%)$ of pollen grains in } \\
\cline { 2 - 3 } & $\begin{array}{c}\text { Pollen trap } \\
(\text { mean } \pm \mathrm{sd})\end{array}$ & $\begin{array}{c}\text { Rectum } \\
(\mathrm{mean} \pm \mathrm{sd})\end{array}$ \\
\hline Ocimum bassilicum (Lamiaceae) & $0.04 \pm 0.08$ & $0.02 \pm 0.05$ \\
Chenopodiaceae & $0.53 \pm 0.54$ & $0.53 \pm 1.12$ \\
Citrus Type & $0.05 \pm 0.10$ & 0 \\
Daucus carota (Apiaceae) & $0.04 \pm 0.15$ & $0.41 \pm 1.79$ \\
Erica manipuliflora* (Ericaceae) & $15.41 \pm 11.23$ & $3.38 \pm 4.29$ \\
Hedera helix (Araliaceae) & $10.39 \pm 5.93$ & $16.64 \pm 16.98$ \\
Liliaceae* & $0.08 \pm 0.14$ & $14.98 \pm 17.29$ \\
Lagerstroemia indica (Lythraceae) & $0.15 \pm 0.36$ & 0 \\
Malva sylvestris (Malvaveae) & $0.04 \pm 0.07$ & $0.01 \pm 0.05$ \\
Phoenix Type & $9.47 \pm 11.84$ & $10.55 \pm 12.26$ \\
Polygonum aviculare* (Polygonaceae) & $28.82 \pm 19.02$ & $15.36 \pm 11.79$ \\
Portulaca oleraceae* (Portulacaceae) & $0.54 \pm 0.83$ & $0.06 \pm 0.21$ \\
Rubus ulmifolius $*$ (Rosaceae) & $0.21 \pm 0.45$ & $2.56 \pm 3.46$ \\
Scholmus hispanicus (Asteraceae) & $1.52 \pm 1.85$ & $0.68 \pm 1.50$ \\
Sisymbrium irio (Brassicaceae) & $31.40 \pm 10.60$ & $28.54 \pm 10.09$ \\
Sonchus Type* & $1.13 \pm 1.12$ & $0.28 \pm 0.69$ \\
Tribulus terrestris (Zygophyllaceae) & $0.19 \pm 0.24$ & $0.23 \pm 0.52$ \\
Zea mays (Poaceae) & $0.02 \pm 0.11$ & $0.03 \pm 0.07$ \\
Unidentified & 0 & $5.73 \pm 3.69$ \\
\hline
\end{tabular}

* Statistically significantly different according to Mann-Whitney test $(\alpha=0.05)$. 

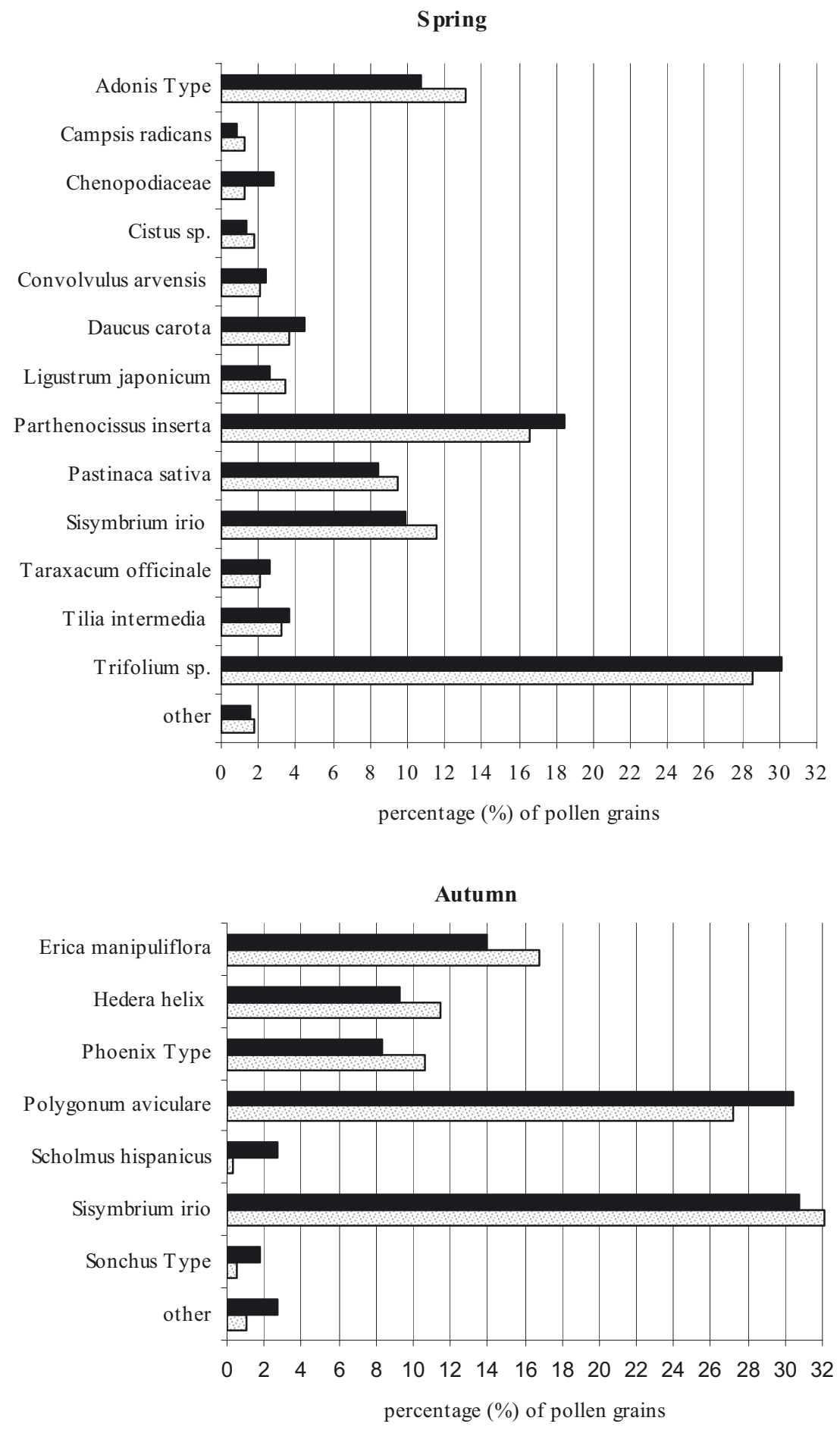

Figure 2. Frequency of pollen types collected by the two colonies (trap A ( $\mathbf{\square})$, trap B (⿴囗口)) in percentages over $1 \%$ in spring and in autumn. 
Table III. Frequency of pollen types in the rectum of nurse bees and various-age bees in autumn.

\begin{tabular}{lcc}
\hline \multirow{2}{*}{ Pollen type* } & \multicolumn{2}{c}{ Percentage (\%) of pollen grains } \\
\cline { 2 - 3 } & $\begin{array}{c}\text { Nurse bees } \\
(\mathrm{mean} \pm \mathrm{sd})\end{array}$ & $\begin{array}{c}\text { Various-age bees } \\
(\mathrm{mean} \pm \mathrm{sd})\end{array}$ \\
\hline Ocimum bassilicum (Lamiaceae) & $0.01 \pm 0.03$ & $0.02 \pm 0.04$ \\
Chenopodiaceae & $0.62 \pm 1.52$ & $0.79 \pm 1.52$ \\
Daucus carota (Apiaceae) & $0.53 \pm 1.94$ & $0.42 \pm 1.94$ \\
Erica manipuliflora (Ericaceae) & $3.93 \pm 4.10$ & $4.50 \pm 2.82$ \\
Hedera helix (Araliaceae) & $17.24 \pm 6.12$ & $14.70 \pm 3.66$ \\
Liliaceae & $15.01 \pm 12.61$ & $15.82 \pm 16.26$ \\
Malva sylvestris (Malvaveae) & $0.01 \pm 0.04$ & $0.02 \pm 0.23$ \\
Phoenix Type & $9.01 \pm 8.56$ & $8.76 \pm 9.21$ \\
Polygonum aviculare (Polygonaceae) & $12.10 \pm 10.34$ & $14.59 \pm 6.80$ \\
Portulaca oleraceae (Portulacaceae) & $0.04 \pm 0.24$ & $0.02 \pm 0.18$ \\
Rubus ulmifolius (Rosaceae) & $2.77 \pm 3.87$ & $2.38 \pm 4.19$ \\
Scholmus hispanicus (Asteraceae) & $0.45 \pm 0.76$ & $0.84 \pm 0.79$ \\
Sisymbrium irio (Brassicaceae) & $31.83 \pm 13.44$ & $31.81 \pm 15.08$ \\
Sonchus Type & $0.03 \pm 0.09$ & $0.07 \pm 0.12$ \\
Tribulus terrestris (Zygophyllaceae) & $0.40 \pm 0.87$ & $0.32 \pm 0.96$ \\
Zea mays (Poaceae) & $0.04 \pm 0.06$ & $0.02 \pm 0.07$ \\
Unidentified & $5.98 \pm 3.53$ & $4.90 \pm 2.86$ \\
\hline
\end{tabular}

* No statistically significant differences were observed according to Mann-Whitney test $(\alpha=0.05)$.

The statistical analysis showed no significant differences between the two groups of honeybees (nurse bees and various-age bees) in autumn concerning the percentage frequency of the pollen types in their rectum (minimum observed $(P=0.083)$ (Tab. III). The same pollen types were also recorded in both groups in spring. Statistical analysis showed significant differences only in two cases: Adonis Type and Parthenocissus inserta (Tab. IV). The percentage frequency of the pollen grains of Adonis Type was higher in the rectum of the nurse bees compared to the various-age bees $(22.7 \pm 5.8 \%$ and $15.8 \pm 2.9 \%$ respectively). In contrast, the percentage frequency of the pollen grains of $P$. inserta was higher in the rectum of the various-age bees compared to the nurse bees $(4.6 \pm 2.1 \%$ and $2.5 \pm 1.1 \%$ respectively).

\section{DISCUSSION}

The higher amount of pollen collected in spring did not influence the total weight of the rectum, and consequently the amount of pollen in the rectum of the nurse bees, com- pared to autumn. This suggests that the use of this method is suitable throughout the year.

Foraging age bees not only consume less amount of pollen, but they also fly and empty their rectum more frequently compared to nurse bees (Crailsheim et al., 1992; Naiem et al., 1999). In this study we found that there were statistically significant differences with respect to the weight of the rectum between the group of the nurse bees and the variousage bees. However, the difference in the weight of the rectum, and consequently the amount of pollen content, did not influence the results. We found no statistically significant differences with respect to the percentage frequency of the pollen types in the rectum between the two groups in autumn and only in two cases (Adonis Type and P. inserta) in spring.

During the days before the introduction of the nurse bees to the hives we observed that the amount of pollen loads in the pollen traps of Adonis Type pollen was increasing, while the amount of $P$. inserta pollen was diminishing. Both this observation and the statistical results mentioned above are in accordance to the conclusions of other authors: nurse bees tend to consume mainly fresh pollen (Doull, 1974). 
Table IV. Frequency of pollen types in the rectum of nurse bees and various-age bees in spring.

\begin{tabular}{lcc}
\hline \multirow{2}{*}{ Pollen type } & Percentage $(\%)$ of pollen grains in \\
\cline { 2 - 3 } & $\begin{array}{c}\text { Pollen trap } \\
\text { (mean } \pm \mathrm{sd})\end{array}$ & $\begin{array}{c}\text { Rectum } \\
(\mathrm{mean} \pm \mathrm{sd})\end{array}$ \\
\hline Adonis Type* & $22.66 \pm 5.75$ & $15.80 \pm 2.87$ \\
Campsis radicans (Bignoniaceae) & $0.17 \pm 0.31$ & $0.12 \pm 0.23$ \\
Carduus Type & $0.04 \pm 0.02$ & $0.02 \pm 0.03$ \\
Chenopodiaceae & $0.47 \pm 0.56$ & $0.89 \pm 0.66$ \\
Convolvulus arvensis (Convolvulaceae) & $0.94 \pm 0.84$ & $0.68 \pm 0.64$ \\
Daucus carota (Apiaceae) & $6.08 \pm 3.94$ & $7.59 \pm 6.64$ \\
Elaeagnus angustifolia (Elaeagnaceae) & $1.18 \pm 1.02$ & $0.84 \pm 1.32$ \\
Ligustrum japonicum (Oleaceae) & $5.13 \pm 1.13$ & $6.66 \pm 3.02$ \\
Olea europea (Oleaceae) & $11.51 \pm 7.96$ & $14.79 \pm 10.12$ \\
Parthenocissus inserta*(Vitaceae) & $2.52 \pm 1.10$ & $4.67 \pm 2.12$ \\
Pastinaca sativa (Apiaceae) & $0.84 \pm 0.94$ & $0.52 \pm 0.64$ \\
Pinus sp. (Pinaceae) & $0.04 \pm 0.27$ & $0.01 \pm 0.03$ \\
Sisymbrium irio (Brassicaceae) & $10.79 \pm 4.45$ & $8.45 \pm 4.16$ \\
Taraxacum officinale (Asteraceae) & $0.73 \pm 0.78$ & $0.90 \pm 1.55$ \\
Thymus Type & $0.09 \pm 0.22$ & $0.33 \pm 0.64$ \\
Tilia intermedia (Tiliaceae) & $2.22 \pm 1.36$ & $1.57 \pm 0.91$ \\
Tribulus terrestris (Zygophyllaceae) & $0.19 \pm 0.27$ & $0.02 \pm 0.06$ \\
Trifolium sp. (Fabaceae) & $1.04 \pm 0.56$ & $0.82 \pm 0.51$ \\
Unidentified & $33.38 \pm 4.95$ & $35.32 \pm 6.85$ \\
\hline
\end{tabular}

* Statistically significantly different according to Mann-Whitney test $(\alpha=0.05)$.

However, the same pollen types were recorded in both groups. Thus, any-age bees of a colony could be used to reveal the bee pollen spectra of an area for a specific time period. Practically, samples of honeybees could be easily collected randomly without requiring previous preparations or colony disturbance at any time during the year and then have their rectums examined for pollen content in the laboratory.

On the other hand, statistical analysis showed significant differences among the two methods that were used to record the pollen flora (pollen trap and rectum analysis), with respect of the percentage frequency of the pollen types in most cases. Most of the pollen types found in the samples came from both polleniferous and nectariferous sources as it has been reported by Crane et al. (1984). In contrast to pollen traps, that only record only the pollen flora, rectum analysis can also reveal pollen grains coming from the nectar (Todd and Vansell, 1942). However, the contribution of pollen from nectar is extremely low compared to directly consumed pollen. A likely explanation for these differences be- tween the two methods was the high percentage of unidentified pollen grains of the rectum analysis. During digestion, a great number of pollen grains can break or shrink. Hence, pollen identification becomes very difficult. Crailsheim et al. (1992) have reported that the number of shrunken and empty pollen grains in the rectum of nurse bees can often be higher than $70 \%$. Similar results have also been reported by Oliveira et al. (2002).

The degree of digestion is affected by the botanical origin, the exine and the intene of the pollen grains (Klungess and Peng, 1984; Peng et al., 1985, 1986; Dobson and Peng, 1997). For example, pollen grains of dandelion are less digested compared to pollen grains with thin wall (Kroon et al., 1974; Peng et al., 1985). On the other hand, pollen identification is mainly based on the sculpture of the exine, the size and the shape of the pollen grains. Since during digestion most of the pollen grains break or shrink, the exine sculpture is critical for the identification. Consequently, pollen grains with distinctive exine ornamentation such as Asteraceae can more 
easily be identified after digestion than other pollens, whose exine surface is smooth.

In this study the percentage of the unidentified pollen grains in the bee rectums was much higher in spring than autumn. Although it is known that during digestion enzymes are more active during spring than autumn (Zherebkin, 1965), the botanical origin of the pollen was also a very likely explanation for this difference. A high percentage of pollen grains of Trifolium sp., were recorded in the traps but not in the rectum during spring. Due to the morphology of the pollen grain, the degree of digestion of Trifolium sp. is relatively high (Crailsheim et al., 1992) making identification difficult. Consequently, the pollen spectra of an area during the year could significantly affect the accuracy of the results coming from the bee rectum analysis.

Although the percentage of unidentified pollen grains found during rectum content examination of honeybees can be relatively high, the great number of pollen grains and the different degree of digestion among the same pollen type (Crailsheim et al., 1992; Fernandes-da-Silva and Serrão, 2000), still allows the analyst to identify and record the full pollen spectra collected by the honeybees in an area. The results accomplished from the analysis of the rectum of the nurse bees and the various age bees were similar to those obtained from pollen pellet analysis with respect to the number of pollen taxa.

In conclusion, the pollen analysis of the rectum of the honeybees can give qualitative information for the bee flora of an area and can be used as a fast screening method, considering the simplicity and time-saving sampling procedure. However, for quantitative results, additional methods such as pollen pellet analysis should be applied.

\section{ACKNOWLEDGEMENTS}

The authors are greatly indebted to the Associate Editor and the two reviewers for their constructive comments. Also, we would like to thank Prof. Dr. M. Yfantidis for his contribution to this research.

Analyse pollinique du rectum de l'Abeille domestique comme méthode pour déterminer les plantes pollinifères d'une région utilisées par les abeilles.

Apis mellifera / consommation alimentaire / pollen / mélissopalynologie / abeille nourrice / flore pollinifère

Zusammenfassung - Pollenanalyse des Enddarms der Honigbienen als Methode zur Bestimmung der Bienenpollenpflanzen in einer Gegend. Die Kenntnis der Bienenpflanzen in einer Gegend ist von grundlegender Bedeutung für die Entwicklung der Imkerei. Pollen ist für die Ernährung der Bienen, ihr Überleben und ihre Reproduktion von essentieller Wichtigkeit. Als Methode der Erfassung der Pollenpflanzen in einer Gegend werden weithin Pollenfallen verwendet, für einige Bienenarten ist dies allerdings nicht praktikabel oder nicht wünschenswert, da die Pollenfallen das Nektarsammeln der Völker negativ beeinflussen. Hier untersuchten wir die Möglichkeit, die Pollenpflanzen in einer Gegend anhand des Pollengehaltes im Enddarm (Apis mellifera L.) zu erfassen und die Ergebnisse mit denen von Pollenfallen zu vergleichen. Wir untersuchten den Pollengehalt des Enddarms von Ammenbienen und Bienen sowie die aus Pollenfallen gewonnenen Pollenladungen aus zwei Völkern im Frühjahr und im Herbst. Die Ergebnisse der Untersuchung zeigten keine Unterschiede in der Häufigkeit verschiedener Pollen zwischen den Ammenbienen und den Bienen unterschiedlichen Alters. Dagegen zeigte eine statistische Analyse in den meisten Fällen signifikante Unterschiede zwischen den beiden Methoden zur Erfassung des Pollens (Pollenfallen und Enddarmanalyse). Wir schließen daraus, dass die Pollenanalyse des Enddarms von Honigbienen als rasches Sichtungsverfahren der Bienenflora in einer Region verwendet werden könnte. Allerdings sollten für eine quantitative Analyse zusätzliche Methoden wie die Untersuchung von Pollenhöschen Verwendung finden.

Apis mellifera / Ammenbienen / Pollenverbrauch / Melissopalynologie

\section{REFERENCES}

Al-Tikrity W.S., Benton A., Hillman R.C., Clarke W.W. (1972) The relationship between the amount of unsealed brood in honey bee colonies and their pollen collection, J. Apic. Res. 11, 9-12.

Andrada A.C., Telleria M.C. (2005) Pollen collected by honey bees (Apis mellifera L.) from south of Calden district (Argentina), botanical origin and protein content, Grana 44, 115-122.

Biesmeijer J.C., van Marwijk B., van Deursen K., Punt W., Sommeijer M.J. (1992) Pollen 
sources for Apis mellifera L. (Hym, Apidae) in Surinam, based on pollen grain volume estimates, Apidologie 23, 245-256.

Camazine S. (1993) The regulation of pollen foraging by honey bees, how foragers assess the colony's need for pollen, Behav. Ecol. Sociobiol. 32, 265272.

Coffey M.F., Breen J. (1997) Seasonal variation in pollen and nectar sources of honeybees in Ireland, J. Apic. Res. 36, 63-76.

Crailsheim K., Schneider L.H.W., Hrassnigg N., Buhlmann G., Brosch U., Gmeinbauer R., Schoffmann B. (1992) Pollen consumption and utilization in worker honeybees (Apis mellifera carnica), dependence on individual age and function, J. Insect Physiol. 38, 409-419.

Crane E., Walker P., Day R. (1984) Directory of important world honey resources, IBRA, London.

Dietz A. (1978) Nutrition of the adult honey bee, in: Graham J.M. (Ed.), The hive and the honey bee, Dadant and Sons, Carthage, Illinois, pp. 125-156.

Dimou M., Thrasyvoulou A., Tsirakoglou V. (2006) Efficient use of pollen traps to determine the pollen flora used by honeybees, J. Apic. Res. 45, $42-46$.

Dimou M., Thrasyvoulou A. (2007) Seasonal variation in vegetation and pollen collected by honeybees in Thessaloniki, Greece, Grana 46, 292-299.

Dobson H.E.M., Peng Y.S. (1997) Digestion of pollen components by larvae of the lower-specialist bee Chelostoma florisomne (Hymenoptera, Megachilidae), J. Insect Physiol. 43, 89-100.

Doull K.M. (1974) Some effects of distance on the attraction of pollen to honeybees in the hive, J. Apic. Res. 13, 27-32.

Dreller C., Page R.E., Fondrk M.K. (1999) Regulation of pollen foraging in honeybee colonies, effect of young brood, stored pollen, and empty space, Behav. Ecol. Sociobiol. 45, 227-233.

Dreller C., Tarpy D.R. (2000) Perception of the pollen need by foragers in a honey colony, Anim. Behav. 59, 91-96.

Duff S.R., Furgala B. (1986) Pollen trapping honey bee colonies in Minnesota, Part II, effect on foraging activity, honey production, honey moisture content, and nitrogen content of adult workers, Am. Bee J. 126, 755-75.

Eischen F.A., Rothenbuhler W.C., Kulincevik J.M. (1984) Some effects of nursing on nurse bees, J. Apic. Res. 23, 90-93.

Fernandes-da-Silva P.G., Serrão J.E. (2000) Nutritive value and apparent digestibility of bee-collected and bee-stored pollen in the stingless bee, Scaptotrigona postica Latr. (Hymenoptera, Apidae, Meliponini), Apidologie 31, 39-45.

Fewell J.H., Winston M.L. (1992) Colony state and regulation of pollen foraging in the honey bees
(Apis mellifera L.), Behav. Ecol. Sociobiol. 30, 387-393.

Hagedorn H.H., Moeller F.E. (1967) The rate of pollen consumption by newly emerged honeybees, J. Apic. Res. 6, 159-162.

Haydak M.H. (1970) Honey bee nutrition, Ann. Rev. Entomol. 15, 146-156.

Hrassnigg N., Crailsheim K. (1998) The influence of brood on the pollen consumption of worker bees (Apis mellifera L.), J. Insect Physiol. 44, 393-404.

Klungness L.M., Peng Y.S. (1984) A histochemical study of pollen digestion in the alimentary canal of honeybees (Apis mellifera L.), J. Insect Physiol. $30,511-521$.

Kroon G.H., Van Praagh J.P., Velthuis H.H.W. (1974) Osmotic shock as a prerequisite to pollen digestion in the alimentary tract of the worker honeybee, J. Apic. Res. 13, 177-181.

Loidl K., Crailsheim K. (2001) Free fatty acids digested from pollen and triolein in he honeybee (Apis mellifera carnica Pollmann) midgut, J. Comp. Physiol. B 171, 313-319.

McLellan A.R. (1974) Some effects of pollen traps on colonies of honeybees, J. Apic. Res. 13, 143-148.

Mehta C., Patel R. (1996) SPSS Exact test 7.0 for Windows, SPSS Inc., Chicago.

Naiem E.S., Hrassnigg N., Crailsheim K. (1999) Nurse bees support the physiological development of young bees (Apis mellifera L.), J. Insect Physiol. B 169, 271-279.

Oliveira G.V., Serrao J.E., Message D. (2002) Digestibility of pollen grains by worker honeybees, Apis mellifera (Hymenoptera, Apidae, Apini) in the microregion of Viscosa, MG, Brazil, Rev. Bras. Zoociencias juiz de Fora 4, 193-201.

Page R.E. Jr., Waddington K.D., Hunt G.J., Fondrk M.K. (1995) Genetic determinants of honey bee foraging behavior, Anim. Behav. 50, 1617-1625.

Pankiw T., Tarpy D.R., Page R.E. Jr. (2002) Genotype and rearing environment affect honeybee perception and foraging behaviour, Anim. Behav. 64, 663-672.

Pankiw T., Page, R.E. Jr., Fondrk W.K. (1998) Brood pheromone stimulates pollen foraging in honey bees (Apis mellifera), Behav. Ecol. Sociobiol. 44, 139-198.

Pearson W.D., Braiden V. (1990) Seasonal pollen collection by honeybees from grass/shrub highlands in Canterbury, New Zealand, J. Apic. Res. 29, 206-213.

Peng Y.S., Nasr M.E., Marston J.M., Yuenzhen F. (1985) The digestion of dandelion pollen by adult worker honeybees, Physiol. Entomol. 10, 75-82.

Peng Y.S., Nasr M.E., Marston J.M. (1986) Release of alfalfa, Medicago sativa, pollen cytoplasm in the gut of the honeybee, Apis mellifera (Hymenoptera, Apidae), Ann. Entomol. Soc. Am. 79, 804-807. 
Ramírez-Arriaga E., Martínez-Hernández E. (1998) Resources foraged by Euglossa atroveneta (Apidae, Euglossinae) at Union Juarez, Chiaps, Mexico. A palynological study of larval feeding, Apidologie 29, 347-359.

Seeley T.D. (1995) The wisdom of the hive: the social physiology of honey bee colonies, Harvard University Press, Cambridge, Mass.

Severson D.W., Parry J.E. (1981) A chronology of pollen collection by honeybees, J. Apic. Res. 20, 97-103.

Szolderits M.J., Crailsheim K. (1993) A comparison of pollen consumption and digestion in honeybee (Apis mellifera carnica) drones and workers, J. Insect Physiol. 39, 877-881.
Telleria M.C. (1993) Floraison et recolte du pollen par les abeilles domestiques (Apis mellifera L. var. ligustica) dans la pampa argentine, Apidologie 24, 109-120.

Todd F.E., Vansell G.H. (1942) Pollen grains in nectar and honey, J. Econ. Entomol. 35, 728-731.

Webster T.C., Thorp R.W., Briggs D., Skinner J., Parisian T. (1985) Effects on pollen traps on honeybee foraging and brood rearing during almond and prune pollination, Environ. Entomol. 14, 683686.

Zherebkin M. (1965) Digestion in bees from weak and strong colonies, Pchelovodstvo 42, 25-27 [in Russian]. 